DOI: https://doi.org/10.36910/6775-2524-0560-2021-44-12

УДК 004.31

Чернящук Наталія Леонідівна, д.п.н., професор

http://orcid.org/0000-0002-3178-8377

Бортник Катерина Яківна, к.т.н., доцент

https://orcid.org/0000-0001-5282-099X

Каганюк Олексій Казимирович к.т.н., доцент

https://orcid.org/0000-0003-4616-8768

Іщук Олександр Миколайович, магістр

Гамонін Назарій Миколайович, магістр

Луцький національний технічний університет

\title{
АНАЛІЗ WЕВ-РЕСУРСІВ ДЛЯ ОРГАНІЗАЦІЇ ТА ПРОВЕДЕННЯ ТЕСТІВ І ОПИТУВАНЬ У НАВЧАЛЬНОМУ ПРОЦЕСІ
}

\begin{abstract}
Чернящук Н.Л., Бортник К.Я., Каганюк О.К., Іщук О.М., Гамонін Н.М. Аналіз wеb-ресурсів для організації та проведення тестів і опитувань у навчальному процесі. У статті здійснено аналіз веб-ресурсів для організації та проведення тестів і опитувань у навчальному процесі, розглянуті завдання щодо забезпечення швидкого здійснення контролю знань та опитування; надання можливості максимально автоматизувати процеси тестування та опитування, використовувати тести і опитування у дистанційному навчанні; забезпечення користувача зручним графічним інтерфейсом, який може працювати як на комп'ютері, так і на мобільному телефоні.
\end{abstract}

Ключові слова: веб-ресурс, навчальний процес, електронні освітні ресурси, освітні веб-ресурси, тестування, опитування.

Чернящук Н.Л., Бортник К.Я., Каганюк А.К., Ищук А.Н., Гамонин Н.М. Анализ wеb-ресурсов для организации и проведения тестов и опросов в учебном процессе. В статье осуществлен анализ веб-ресурсов для организации и проведения тестов и опросов в учебном процессе, рассмотрены задачи по обеспечению быстрого осуществления контроля знаний и опроса; предоставление возможности максимально автоматизировать процессы тестирования и опросы, использовать тесты опросы в дистанционном обучении; обеспечение пользователя удобным графическим интерфейсом, который может работать как на компьютере, так и на мобильном телефоне.

Ключевые слова: веб-ресурс, учебный процесс, электронные образовательные ресурсы, образовательные вебресурсы, тестирование, опрос.

Chernyashchuk N.L, Bortnyk K.Ya., Kaganyuk A., Ishchuk O.M, Gamonin N.M. Analysis of web-resources for organizing and conducting tests and surveys in the educational process. The article analyzes the web resources for organizing and conducting tests and surveys in the educational process, considers the tasks to ensure the rapid implementation of knowledge control and surveys; providing the opportunity to automate the processes of testing and questioning, use tests and surveys in distance learning; providing the user with a user-friendly graphical interface that can work on both a computer and a mobile phone.

Keywords: web resource, educational process, electronic educational resources, educational web resources, testing, surveys.

Постановка проблеми. У сучасному світі за останні роки з розвитком сучасних технологій, поширенням і доступністю Інтернет-зв'язку відкриваються унікальні можливості для освіти. Інтернет це не лише невичерпна скарбниця освітньої інформації, а й джерело активної інтелектуальної діяльності сучасного студента, який має необмежені можливості для одержання знань, удосконалення умінь, навичок. Викладачеві, у свою чергу, надається можливість оптимізувати систему контролю, зокрема переводячи тестування в режим онлайн. Значний інтерес до створення та використання освітніх вебресурсів обумовлений серйозними, i в значній мірі, обгрунтованими очікуваннями підвищення ефективності навчального процесу і якості навчання.

Задачі, які повинні вирішуватись:

- забезпечення користувача персональним кабінетом, в якому можна створювати тести i опитування;

— забезпечення дуже швидкого здійснення контролю знань та опитування;

- надання можливості максимально автоматизувати процеси тестування та опитування, використовувати тести і опитування у дистанційному навчанні;

- забезпечення користувача зручним графічним інтерфейсом, який може працювати як на комп'ютері, так і на мобільному телефоні.

Вхідними даними мають бути: інформація про тести та опитування, що зберігається у базі даних.

Вихідними даними мають бути: HTML-сторінка 3 відображенням інформації про тест чи опитування.

Результатами роботи мають бути: результати пройдених тестів та опитувань. 
Для зручності користування мають бути: розроблений пошук, зручність представлення інформації (наглядне меню, короткий огляд інформації по тестах чи опитуваннях, 3 можливістю перегляду повних результатів).

Програмне забезпечення має бути 3 декількома програмними засобами реалізації, архітектура програмної системи має складатися з трьох компонентів: клієнт, сервер і база даних.

Користувачами системи мають бути:

- адміністратор системи;

- викладач;

- студент.

Адміністратор системи повинен мати можливість реєструвати у системі викладачів та студентів, редагувати інформацію про них, при необхідності видаляти застарілу інформацію.

Викладачі повинні мати можливість створювати тести i опитування, а також переглядати результати їх проходження студентами.

Студенти повинні мати можливість знайти потрібний тест чи опитування для його проходження, а також переглядати результати пройдених тестів і опитувань.

Система повинна надавати повну інформацію про тести і опитування, створені викладачами для студентів. Ресурс повинен бути швидким у інтерпретації найпоширенішими браузерами.

Огляд існуючих програмних рішень організації та проведення тестів i опитувань у навчальному процесі. 3 кожним роком набувають все більшого поширення різноманітні веб-ресурси.

На їх основі вже побудовано багато різноманітного програмного забезпечення, яке вирішує дуже широкий спектр прикладних задач. Серед них можна виділити і задачу організації та проведення тестів і опитувань у навчальному процесі. У процесі пошуку інформації, та аналізу існуючих рішень, було виявлено, що на даний момент такі системи є досить складними у використанні, або реалізують поставлену задачу не в повному обсязі:

— Освітній веб-ресурс "Perfect English Grammar" являє собою довідник, а також збірник різноманітних вправ та онлайн-тестів з граматики англійської мови.

Недоліком даної системи для поставленої задачі можна вважати, що вона не має можливості авторизуватися у системі, оскільки авторизація дає змогу зберегти отримані результати;

— Веб-ресурс "Quizlet” — це ресурс для вивчення іноземних мов, у якому користувачі мають змогу тренуватися, виконуючи різні завдання та тести. Дане

програмне забезпечення не реалізує поставлену задачу в повному обсязі, оскільки цей ресурс використовується виключно для підготовки до іспитів, а не для їх проходження.

Також недоліком цих систем є їх громіздкість. Для початківців ці програми можуть здатися переповненими функціоналом та дуже специфічними в плані налаштування.

Так як автоматизація проведення тестів у навчальному процесі набуває широкого розповсюдження, то розробка зручної, інтуїтивно зрозумілої, гнучкої та невимогливої до апаратного забезпечення системи для проведення тестів і опитувань $\epsilon$ актуальною задачею.

Одним із варіантів, який зможе працювати на будь-яких сучасних пристроях, є розробка програмної системи, яка заснована на веб-технологіях.

Веб-ресурсів для організації тестів і опитувань у навчальному процесі. Веб-ресурс - це сукупність інтегрованих засобів технічного і програмно-апаратного характеру, а також інформації, призначеної для публікації у Всесвітній мережі.

Навчальний процес - це система організаційних і дидактичних заходів, спрямованих на реалізацію змісту освіти на певному освітньому або кваліфікаційному рівні відповідно до державних стандартів освіти.

Навчальний процес організовується 3 урахуванням можливостей сучасних інформаційних технологій навчання та орієнтується на формування освіченої, гармонійно розвиненої особистості, здатної до постійного оновлення наукових знань, професійної мобільності та швидкої адаптації до змін $\mathrm{i}$ розвитку в соціальнокультурній сфері, в галузях техніки, технологій, системах управління та організації праці в умовах ринкової економіки.

Електронні освітні ресурси є складовою частиною навчального процесу. Вони мають навчальнометодичне призначення та використовуються для забезпечення навчальної діяльності студентів $\mathrm{i}$ вважаються одним 3 головних елементів інформаційно-освітнього середовища. Одним 3 різновидів електронних освітніх ресурсів $є$ освітні веб-ресурси. Використання сучасних веб-технологій дає змогу суттєво вдосконалити систему освіти, а отже, ії подальша інформатизація - процес незворотний та обов'язковий. Освітні веб-ресурси у даній ситуації є оптимальним інструментом 
удосконалення професійної підготовки сучасних педагогів. Розробка дистанційних курсів, забезпечення більшості вишівських спеціальностей дистанційними формами навчання вимагає грамотного вибору програмно-технічного оснащення цього процесу, знання існуючих платформ дистанційного навчання, вибору найбільш придатної для конкретного курсу.

Паралельно має вестись робота із забезпечення дистанційного навчання навчальними засобами. Зараз серед електронних навчальних засобів, створених для дистанційного навчання, все більш значущими стають освітні веб-ресурси, зокрема веб-сайти, блоги.

Освітні веб-ресурси — це освітні електронні ресурси, що розміщенні у веб-просторі локальної чи глобальної мережі у вигляді різних форматів (текстового, графічного, архівного, аудіо- та відеоформатів) [1].

За функціональним призначенням вони поділяються на:

- навчальні;

- навчально-методичні;

— довідкові;

- нормативні;

— наукові;

- педагогічні;

— програмні засоби.

Таким чином, освітні веб-ресурси (сайти, блоги) передбачають інформаційно-презентаційну, консультативну, інформаційно-методичну, просвітницьку, навчальну підтримку діяльності суб'єктів взаємодії, відкривають нові можливості взаємодії з громадськістю та дозволяють:

- інтерактивно донести інформацію до аудиторії незалежно від іiі територіального місцезнаходження;

— оперативно висвітлювати діяльність веб-ресурсу на основі публікації новин,

оглядів, каталогів видань, а також наукових, методичних і практичних матеріалів;

- використовувати сучасні засоби спілкування, такі як: електронна пошта, інтерактивні конференції, форум - та ефективно організувати службу підтримки порталу;

— активізувати участь педагогічних працівників та учнів в Інтернет-олімпіадах, конкурсах, конференціях.

Застосування інформаційного простору в галузі освіти і безпосередньо в діяльності педагога стало загальною необхідністю. Освітні веб-ресурси можуть і повинні стати для педагогічної громадськості одним 3 пріоритетних засобів і способів самоосвіти; вони $є$ ефективним організаційним елементом регіональної системи освіти, адже нові інформаційні технології впливають на всі компоненти освіти: зміст, методи та організаційні форми навчання, дозволяють вирішувати складні та актуальні завдання педагогу для забезпечення його інтелектуально-творчого розвитку.

Одним із шляхів підвищення якості освіти $є$ підвищення ефективності контролю знань. Здійснення контролю в навчальному процесі має на меті виявити якість засвоєння знань, виміряти іiі величину та присвоїти цій якості певну оцінку.

Перевірка й оцінка знань студентів $є$ активним процесом. Викладач не тільки пасивно реєструє фактичні знання студентів, а й впливає на хід і результати всього навчального процесу. Його завдання - знайти найефективніший засіб перевірки знань, щоб виявити досягнення студентів і стимулювати їх надалі оволодівати знаннями.Необхідно створювати таку атмосферу, щоб студент обов'язково працював систематично, проявляючи наполегливість та вольові зусилля. Одним із шляхів здійснення цієї мети $€$ тестовий контроль знань. Тестування або тестовий контроль знань - це засіб об'єктивного контролю ступеня досягнення кінцевих цілей підготовки студентів при якому рівень сформованості умінь встановлюється опосередковано за допомого ситуаційних тестів [2].

Переваги тестового контролю знань:

- об'єктивність - незалежність результатів тестування від особистих стосунків викладача та студента; простота процедури запису (введення) відповіді, незалежність оцінки від техніки письма;

— кількісні критерії оцінки — наявність кількісних показників для визначення

повноти та глибини засвоєння матеріалу;

— простота та формалізованість процедури визначення оцінки — можливість іiі

здійснення людиною середньої кваліфікації або технічним пристроєм;

- чіткість та однозначність формулювання умов тестових завдань - що забезпечує однозначність сприйняття студентами їх змісту;

- рівні вимоги до знань та умінь студента шляхом використання в тесті завдань однакової складності, обсягу та змісту; 
перевірки;

— забезпечення необхідної повноти охоплення знань та умінь, що контролюватимуться під час

— можливість одночасної перевірки значної кількості студентів;

— можливість багаторазового повторення умов перевірки, для з'ясування змін

в рівні підготовки;

— орієнтація на сучасні освітні технології - використання комп'ютерних навчальних i контролюючих систем;

- універсальність — охоплення всіх етапів процесу навчання;

— багатофункціональність - контроль, діагностика, корекція навчального

процесу;

— охоплює контролем великий обсяг матеріалу;

- упродовж досить обмеженого часу може бути перевірена якість знань, навичок у зазначеної кількості студентів;

— можливий контроль знань, умінь, навичок на необхідному, заздалегідь запланованому рівні;

- реальним є самоконтроль;

— увага студента фіксується не на формуванні відповіді, а на осмисленні їі суті;

- створюють умови для постійного зворотного зв'язку між студентом і викладачем. висновків:

Тестовий контроль знань як вирішення проблеми підвищення якості освіти приводить до

- урізноманітнення форм і засобів контролю якості знань студентів $є$ актуальною проблемою, розв'язання якої викликане потребами педагогічної практики і перспективами інтеграції освітньої системи України з європейською спільнотою;

- використання тестових завдань, зокрема, з дисциплін, пов'язаних з комп'ютерною технікою та у комп'ютерній формі, практикується у більшості закордонних університетів і знаходить відгук в українській вищій школі [3];

- запровадження у навчальний процес вітчизняних навчально-методичних розробок здійснюється поступово завдяки співпраці викладачів вищих технічних i вищих педагогічних навчальних закладів;

— процес швидкого старіння наукової інформації потребує від викладачів постійного оновлення не лише лекційного матеріалу, але і відповідних контрольних тестових завдань і супровідних навчальнометодичних матеріалів;

— студентів вищих навчальних закладів доцільно готувати до тестування систематично, на всіх курсах навчання та під час практики.

Традиційні методи перевірки й оцінки знань у поєднанні 3 новими технологіями відкривають перед викладачами широкі можливості. Оптимальним є контроль знань за допомогою тестування. Незаперечно, що підвищення якості навчання студентів безпосередньо пов'язане зі створенням i послідовним використанням системи тестового контролю засвоєння знань [4]. Позначена проблема набуває особливої актуальності в наш час, коли здійснюються суттєві кроки у напрямі інтеграції української системи вищої освіти до європейської університетської спільноти, набувають розповсюдження і підтримки ідеї так званого "Болонського процесу". Якість освіти в першу чергу залежить від якості роботи викладача. Відповідно, питання контролю та оцінки якості роботи викладача $\epsilon$ однією зі складних і важливих завдань в управлінні якістю освіти.

Однією з методик оцінки роботи викладачів може бути, наприклад, опитування студентів через певні проміжки часу або по закінченні вивчення окремих дисциплін [5].

Опитування - це метод збору соціологічної інформації про досліджуваний об'єкт під час безпосереднього або опосередкованого спілкування того хто опитує з особою, яка відповідає на питання.

Використання опитування студентів для визначенні якості викладання дозволить більш ефективно вирішувати питання контролю та оцінки якості роботи викладача, воно є умовою вдосконалення професійних знань і педагогічної майстерності викладача [6]. Для студентів опитування дає можливість не просто оцінити викладача, а й оцінити себе як учасника освітнього процесу. Також опитування можуть допомогти студентам і викладачам у організаційних питаннях.Використання постійного контролю знань у навчальному процесі значно підвищує мотивацію навчання, а опитування покращують якість освітнього процесу, однак для проведення тестування чи опитування викладачі мають виконати велику кількість роботи для формування завдань та організації процесу. Тому важливим рішенням цієї проблеми $є$ використання веб-ресурсів для організації тестів і опитувань, що дозволяє дуже швидко здійснювати контроль, максимально автоматизувати процеси тестування і опитування, а також використовувати тести і опитування у дистанційному навчанні. 
Висновки. У ході аналізу існуючого програмного забезпечення та проведення тестів і опитувань у навчальному процесі було досліджено системи, які слугують для вирішення поставлених задач.

Розроблений програмний продукт дозволяє автоматизувати процеси тестування

і опитування та допомагає це зробити дуже швидко.

Проведено огляд методів і засобів розробки програмної системи. Обгрунтовано

вибір створення програмної системи, заснованої на веб-технологіях, а також побудованої за триланковою архітектурою. Це дає змогу підвищити гнучкість та зручність системи, як у розробці та супроводі, так і у використані.

За результатами виконання тестових завдань підтверджена коректність отриманих результатів, отже система відповідає поставленим вимогам. Користувачами системи можуть бути викладачі, які створюють тести чи опитування, студенти, які їх проходять, а також адміністратори системи, які можуть змінювати інформацію про викладачів та студентів. Програмне забезпечення може бути використано на будь-якій операційній системі, на якій встановлено браузер, який підтримує останні веб-стандарти, а також яка має постійний доступ до інтернету.

Отже, практика покращила знання різноманітних технологій, що використовуються під час розробки програмного забезпечення. Також було створено декілька прототипів програмного забезпечення, які вирішували різноманітні аспекти поставленої задачі, а також які лягли в основу розробленого програмного забезпечення.

Список бібліографічного опису:

1. Биков В.Ю., Лапінський В.В. Методологічні та методичні основи створення і використовування електронних засобів навчального призначення // Комп’ютер у школі та сім’ї. — №3 . — 2012. С. 3-6..

2. Майоров А. Н. Теория и практика создания тестов для системы образования / Майоров А. Н. - М.: Народное образование, 2000. - $352 \mathrm{c}$.

3. Адаменко О.В., Духовна М.М., Панченко Л.Ф. та ін. Тестові завдання для контролю знань в курсі "Обчислювальна техніка і технічні засоби навчання": Навч.-метод, посібник / За ред. Т.О. Козлакової. — К.: ВІПОЛ, 1996.-84 с.

4. Алексейчук І.С. Про технологію створення системи тестування / I.С. Алексейчук // Нові технології навчання: Науково-методичний збірник. - К.: НМЦВД, 2000. — С.43-92.

5. Тетьякова Н. В. Оценка качества работы преподавателя на основе методики многомерного анализа его деятельности / Н. В. Третьякова // Научно-теоретический журнал "Ученые записки университета имени П. Ф. Лесгафта". - 2011. 一 №11(81). - C. 151-155.

6. Васильева, Е. Ю. Подходы к оценке качества деятельности преподавателя вуза // Университетское управление: практика и анализ. - 2006. - № 2 (11). - С. 74-78.

7. What is REST? [Електронний ресурс]. — Режим доступу: http://www.restapitutorial.com/lessons/whatisrest.html.

8. Markus Egger - MVVM Survival Guide for Enterprise Architectures in Silverlight and WPF [Електронний ресурс]. 2012. - Режим доступу: https://www.packtpub.com/application-development/mvvm-survival-guideenterprisearchitectures-silverlight-and-wpf.

9. Кейт Джонс. DOM Scripting: Web Design with JavaScript and the Document Object Model. / К. Джонс — Перше, 2005. $368 \mathrm{c}$.

10. Anthony Gore - Full-Stack Vue.js 2 and Laravel 5 [Електронний ресурс]. - 2015. — Режим доступу: https://bit.ly/2OEODzR.

11. Martin Fowler - GUI Architectures. Часть 1 [Електронний ресурс]. — 2009. — Режим доступу: https://bit.ly/2CvCk1e.

12. Vue.js Material Component Framework - Vuetify.js [Електронний ресурс]. — 2016. — Режим доступу: https://vuetifyjs.com.

13. Дмитрий Котеров, Алексей Костарев РНР. В подлиннике. / Д. Котеров, А. Костарев - Спб.: «БХВ-Петербург», 2005. $-1120 \mathrm{c}$.

14. Колисниченко Д. Н. Самоучитель РНР 5 / Д. Н. Колисниченко - СПб.: Наука и Техника, 2007. — 640 с.

15. Кузнецов Максим, Симдянов Игорь РНР 5/6. / М. Кузнецов, И. Симдянов - Спб.: «БХВ-Петербург», 2009. - 1024 с.

16. Кузнецов Максим, Симдянов Игорь Объектно-ориентированное программирование на РНР. / М. Кузнецов, И. Симдянов - Спб.: «БХВ-Петербург»,

2007. $-608 \mathrm{c}$

17. Л. Аткінсон, 3. Сураскін. РНР5. Бібліотека професіоналу. / Л. Аткінсон, З. Сураскін — М. : «Вільямс», $2006-543$ с. References.

1. Scott Hawkins. Apache web server administration and e-commerce guide. / S. Hawkins. - M .: «Williams», 2001. - $336 \mathrm{p}$

2. Hawkins S. Administration of the Apache Web server / S. Hawkins - M .: Williams, 2001. - $336 \mathrm{p}$

3. Beaulieu A. - $\quad$ Learning SQL [Electronic resource]. - $2005 . \quad$ - Access mode:http://shop.oreilly.com/product/9780596007270.do.

4. Robert Sheldon, Joffrey Moye MySQL: Basic Course Beginning MySQL. / R. Sheldon, D. Moye - M .: "Dialectics" 2007. -880 p.

5. MySQL. Directory. MySQL AB. - M: "Williams", 2006 - 521 p

6. Kuznetsov Maxim, Simdyanov Igor MySQL on examples. / M. Kuznetsov, I. Simdyanov - St. Petersburg: BHVPetersburg, 2008. - 952 p

7. Leon AG PHP 5. Professional Library / AG Leon - M .: Williams, 2006. - 944 p. 